The old question, "Will it make me live longer, doctor ?" may produce the candid reply, "Yes, maybe, but it will certainly seem longer." In the Australian National Blood Pressure Study a grand total of 1721 patients had to be treated for four years to prevent only 10 deaths. ${ }^{4}$ As increasing numbers of people with mild hypertension are now being treated we should give careful thought to the adverse effect of treatment on their quality of life before we assume we are doing good.

J S GILL Research registrar

D G BEEVERS Senior lecturer in medicine

Dudley Road Hospital,

Birmingham B18 7QH

${ }^{1}$ Veterans Administration Cooperative Study Group on Antihypertensive Agents. Effects of treatment on morbidity in hypertension II. Results in patients with diastolic pressure averaging 90 through $114 \mathrm{~mm} \mathrm{Hg.} \mathcal{F} A M A$ $1970 ; 213: 1143-52$.

2 Veterans Administration Cooperative Study Group on Antihypertensive Agents. Effects of treatment on morbidity in hypertension II. Influence of age, diastolic pressure, and prior cardiovascular disease : further analysis of side effects. Circulation 1972;45:991-1004.

${ }^{3}$ Hypertension Detection and Follow-up Program Cooperative Group. Five-year findings of the hypertension detection and follow-up program. 1 . Reduction in mortality of persons with high blood pressure, including mild hypertension. FAMA $1979 ; 242: 2562-71$.

Australian National Blood Pressure Study Management Committee. The Australian therapeutic trial in mild hypertension. Lancet $1980 ; \mathrm{i}: 1261-7$.

${ }^{5}$ Bulpitt CJ, Dollery CT, Carne S. Changes in symptoms of hypertensive patients after referral to hospital clinic. Br Heart $\mathcal{F}$ 1976;38:121-8.

${ }^{6}$ Barlow DH, Beevers DG, Hawthorn VM, Watt HD, Young GAR. Blood pressure measurement at screening and in general practice. $\mathrm{Br}$ Heart $\mathcal{f} 1977 ; 39: 7-12$

Cochrane R. Neuroticism and discovery of high blood pressure. $\mathcal{F}$ Psychosom Res $1969 ; 13: 21-5$.

${ }^{8}$ Monk M. Psychologic status and hypertension. Am $\mathcal{F}$ Epidemiol 1980;112: 200-8.

${ }^{9}$ Haynes RB, Sackett DL, Taylor DW, Gibson ES, Johnson AL. Increased absenteeism from work after detection and labeling of hypertensive patients. N Engl f Med 1978;299:741-4.

${ }^{10} \mathrm{Mann}$ AH. The psychological effect of a screening programme and clinical trial for hypertension upon the participants. Psychol Med 1977;7:431-8.

${ }^{11}$ Medical Research Council Working Party on Mild to Moderate Hypertension. Adverse reactions to bendrofluazide and propranolol in treatment of mild hypertension. Lancet 1981 ;ii:539-42, 3.

12 Bulpitt CJ, Dollery CT, Carne S. A symptom questionnaire for hypertensive patients. 7 Chronic Dis 1974;27:309-23.

${ }^{13}$ Jachuck SJ, Brierley H, Jachuck S, Willcox PM. The effect of hypotensive drugs on the quality of life. $\mathcal{F} R$ Coll Gen Pract 1982;32:103-5.

\section{Chest pain in patients with normal coronary arteriograms}

Studies of patients with persistent chest pain but normal coronary arteries have consistently shown that the risk of subsequent myocardial infarction is low. ${ }^{1-7}$ As a corollary, no demonstrable abnormality of the coronary arteries is found in $1-12 \%$ of patients who do sustain a myocardial infarction. ${ }^{8} 9$

Up to a third of patients with chest pain who undergo coronary arteriography have no arterial abnormalities, ${ }^{10-12}$ yet half ${ }^{5}$ to three quarters ${ }^{6}$ of them remain appreciably disabled after the investigation. In a recent study (p 1505) Bass et al showed that one year after normal coronary arteriography $41 \%$ of patients still complained of chest pain, $46 \%$ had morbid fears, and $24 \%$ were unable to work. A previous study reported persistent symptoms in $94 \%$ of patients, ${ }^{4}$ while in another $73 \%$ improved; most studies report an overall improvement in about half of the cases, although some $22 \%$ to $51 \%{ }^{2}$ of patients were unable to return to work. Faxon et al argue that arteriography is justified by an improvement in physical activity and a decline in the consultation rate after normal coronary arteriography, ${ }^{13}$ but the residual disability which follows this investigation offers no grounds for complacency.

Given these facts, understandably the management of these patients may be difficult. Most studies have shown a low subsequent cardiac mortality in patients with normal coronary arteriograms, who have been told that they are not suffering from structural heart disease and that there is no need to limit their physical activity. At the same time a warning should be sounded. Fox believes that these patients need to be followed up carefully and that subsequent episodes of chest pain must be treated promptly. ${ }^{14}$

So how may these contrasting approaches be reconciled? A stressful event which threatens personal survival or disrupts an individual's close attachments-for example, the loss of a spouse, a treasured object, or a valued status-may be associated with both emotional disturbance and increased mortality even in stable people. ${ }^{15}$ Some evidence suggests that the broken heart is a reality, ${ }^{16}$ and it is not too speculative to suggest that some of these deaths result from spasm in otherwise normal coronary arteries. "Spoiling" an individual's home through flood or burglary is also associated with a significant increase in morbidity and mortality. ${ }^{17}$

Intimations of mortality, whether through participation in an accident which might have been fatal, ${ }^{18}$ witnessing the death of comrades, ${ }^{19}$ or actually experiencing a sudden pain in the chest, are all associated with acute anxiety, which may persist and become disabling. Common features of such anxiety are disordered breathing, chest pain, or oppression and an impending sense of doom. In the American civil war Da Costa described "the irritable heart of the soldier," and "disorderly action of the heart" in the first world war and "effort syndrome" in the second world war were commonplace. The characteristic symptoms of these syndromes were left sided chest pain, breathlessness, palpitations, and fatigue. ${ }^{20}$

Psychogenic disorders may thus simulate heart disease, and psychological factors may precipitate myocardial infarction in the absence of coronary artery disease.$^{21} 22$

Fit patients without coronary artery disease should be told firmly that they need not restrict their physical activity and that their subjective experiences do not presage death. Anyone who consults a doctor should be advised to give up smoking, avoid obesity, and undertake regular exercise. It is probably best for patients not to know that they have had a "mild heart attack," for subsequent anxiety may well outweigh any benefits which may accrue from accepting medical advice. ${ }^{23}$

Extensive cardiac investigations should be avoided when possible, for patients with angina and normal coronary arteries can often be distinguished clinically ${ }^{1}$; indeed, according to Todd, ${ }^{23}$ the history is the most important pointer to the cause of recurrent chest pain. Patients without cardiac abnormalities must be identified and if an emotional disturbance is suspected it is necessary to make a specific diagnosis so that effective treatment may be given.

Depression is frequently associated with pain and may be accompanied by a sense of precordial oppression. Treatment with non-cardiotoxic tricyclic antidepressants such as mianserin should result in a complete recovery. Grief may simulate heart disease and patients should be asked about recent bereavement, particularly through heart disease or sudden 
death. Appropriate counselling and support may then lead to relief of symptoms.

An unexplained breathing disorder was found in $65 \%$ of patients in a recent study, ${ }^{24}$ and this was reduced to $50 \%$ after arteriography. The hypoventilation syndrome $e^{25}$ may be distinguished from other anxiety states by the precipitation of typical symptoms by voluntary overbreathing and by the termination of spontaneous attacks by controlled breathing or rebreathing into a paper bag. Support and reassurance with occasional short term sedation with benzodiazepines may be required initially, but many patients will achieve complete control over their symptoms.

The status of the "hyperdynamic $\beta$ adrenergic circulatory state" ${ }^{26}$ is less certain. Panic attacks, chest pain, and palpitations may be induced by beta adrenergic agents, and beta blockers such as propranolol may reverse or suppress such attacks.

A recent revision of American psychiatric nomenclature ${ }^{27}$ includes a diagnostic category 300.01 panic disorder, whose criteria include chest pain or discomfort, choking or smothering sensations, dyspnoea, palpitations, and fear of dying. There are now several claims that this syndrome responds to treatment with tricyclic antidepressants. ${ }^{28-30}$ Mixed neurotic states, often with symptoms of both anxiety and depression, may require drug treatment to control symptoms and supportive psychotherapy. Patients with residual chest pain but no evidence of physical or emotional disorder may be treated with (among other agents) nitrates, advised to avoid coronary risk factors, and given regular positive counselling from their general practitioner.

The exceptional patient may sustain a subsequent myocardial infarction but this is likely to be recognised and dealt with promptly. More common, but harder to recognise, is the patient who denies emotional distress or stressful life events but goes on to manifest unequivocal but still unacknowledged evidence of their effects. It is this group which is most likely to tax the physician's therapeutic skills.

Professor of Psychiatry,

SYDNEY BRANDON

University of Leicester,

Leicester LE2 6LX

${ }^{1}$ Day LJ, Sowton E. Clinical features and follow-up of patients with angina and normal coronary arteries. Lancet 1976;ii:334-7.

2 Ockene IS, Shay MJ, Alpert JS, Weiner BH, Dalen JE. Unexplained chest pain in patients with normal coronary arteriograms. A follow-up study of functional status. N Engl f Med 1980;303:1249-52.

${ }^{3}$ Waxler EB, Kimbiris D, Dreifus LS. The fate of women with normal coronary arteriograms and chest pain resembling angina pectoris. Am 7 Cardiol $1971 ; 28: 25-32$.

4 Isner JM, Salem DN, Banas JS Jr, Levine HJ. Long-term clinical course of patients with normal coronary arteriography: follow-up study of 121 patients with normal or nearly normal coronary arteriograms. Am Heart f $1981 ; \mathbf{1 0 2}: 645-53$.

5asternak RC, Thibault GE, Savoia M, De Sanctis RW, Hutter AM Jr. Chest pain with angiographically insignificant coronary arterial obstruction. Clinical presentation and long-term follow-up. $\mathrm{Am} \mathcal{F} \mathrm{Med}$ $1980 ; 68: 813-7$.

${ }^{6}$ Lavey EB, Winkle RA. Continuing disability of patients with chest pain and normal coronary arteriograms. $\mathcal{F}$ Chronic Dis $1979 ; 32: 191-6$.

${ }^{7}$ Proudfit WL, Bruschke AVG, Sones FM. Clinical course of patients with normal or slightly or moderately abnormal coronary arteriograms: 10-year follow-up of 521 patients. Circulation 1980;62:712-17.

${ }^{8} \mathrm{Khan} \mathrm{AH}$, Haywood LJ. Myocardial infarction in nine patients with radiologically patent coronary arteries. $N$ Engl 7 Med 1974;291:427-31.

${ }^{9}$ Arnett EN, Roberts WC. Acute myocardial infarction and angiographically normal coronary arteries: an unproven combination. Circulation 1976; 53:395-400.

${ }^{10} \mathrm{Kemp}$ HG Jr, Vokonas PS, Cohn PF, Gorlin R. The anginal syndrome associated with normal coronary arteriograms: report of a six year experience. Am f Med 1973;54:735-42.

${ }^{11}$ Marchandise B, Bourassa MG, Chaitman BR, Lesperance J. Angiographic evaluation of the natural history of normal coronary arteries and mild coronary atherosclerosis. Am $\mathcal{f}$ Cardiol 1978;41:216-20.
12 Proudfit WL, Shirey EK, Sones FM Jr. Selective cine coronary arteriography: correlation with clinical findings in 1,000 patients. Circulation $1966 ; 33: 901-10$

${ }^{13}$ Faxon DP, McCabe CH, Kreigel DE, Ryan TJ. Therapeutic and economic value of a normal coronary angiogram. Am f Med 1982;73: $500-5$.

${ }^{14}$ Fox KM. Myocardial infarction and the normal coronary arteriogram. (Editorial.) Br Med f 1983;287:446-7.

${ }^{15}$ Parkes CM. Bereavement. Studies of grief in adult life. London: Tavistock Publications, 1972.

${ }_{16}$ Parkes CM, Benjamin B, Fitzgerald RG. Broken heart: a statistical study of increased mortality among widowers. Br Med f 1969;i:740-3.

17 Bennet G. Bristol floods 1968. Controlled survey of effects on health of a local community disaster. Br Med f 1970;iii:454-8.

${ }^{18}$ Adler A. Two different types of post-traumatic neurosis. Am $\mathcal{F}$ Psychiatry

$1945 ; 102: 237-40$.
${ }^{19}$ Grinker RR, Spiegel JP. War neuroses. Philadelphia: The Blakiston Co, $\frac{\overline{\bar{S}}}{\bar{D}}$ 1945

${ }^{20}$ Wood P. Da Costas syndrome (or effort syndrome). Br Med f 1941 ; i. ڤ

DeBacker G, Kornitzer M, Kittel F, Dramaix M. Behavior, stress, and $\vec{\circ}$ psychosocial traits as risk factors. Prev Med 1983;12:32-6.

${ }^{22}$ Groen JJ. Psychosomatic aspects of ischaemic (coronary) heart disease. $\overrightarrow{\vec{\omega}}$ In: Hill $\mathrm{O}$, ed. Modern trends in psychosomatic medicine 3. London: Butterworths, 1976:288-329.

${ }^{23}$ Todd JW. Query cardiac pain. Lancet 1983;ii:330-2.

${ }^{21}$ Bass C, Cawley RH, Wade C, et al. Unexplained breathlessness and psychiatric morbidity in patients with normal and abnormal coronary arteries. Lancet 1983; :605-9.

${ }^{25}$ Lum LC. Hyperventilation and anxiety states. $\mathcal{F} R$ Soc Med $1981 ; 74: 1-4$.

${ }^{26}$ Frohlich ED, Tarazi RC, Dustan HP. Hyperdynamic $\beta$-adrenergic circulatory state. Increased $\beta$-receptor responsiveness. Arch Intern Med $1969 ; \mathbf{1 2 3}: 1-7$

27 American Psychiatric Association. Diagnostic and statistical manual of mental disorders. 3rd ed. Washington DC: American Psychiatrico Association, 1980.

${ }^{28}$ Zitrin CM, Klein DF, Woerner MG. Behavior therapy, supportive $\vec{\oplus}$ psychotherapy, imipramine, and phobias. Arch Gen Psychiatry 1978; 35:307-16.

${ }^{29}$ Sheehan DV, Ballenger J, Jacobsen G. Treatment of endogenous anxiety with phobic, hysterical, and hypochondriacal symptoms. Arch Genz Psychiatry 1980;37:51-9.

${ }^{30}$ Klein DF. Anxiety reconceptualized: early experience with imipramine $\frac{\mathbb{D}}{-}$ and anxiety. Compr Psychiatry 1980;21:411-27.

\section{A better deal for overseas doctors}

Some of the most distinguished members of our profession and many others who provide indispensable service first came to Britain as "overseas doctors". The problems facing these doctors seem likely to become worse in the immediate future.

The last few years have seen competition for good senior: house officer posts increase as British medical schools have increased their output of doctors and vocational training pro-o grammes for general practice have burgeoned. Too often, foreign graduates find that they are unable to get good jobs in 궁 the specialty which they wish to study and they fail the examin- $N$ ations which they had hoped would testify on their return home? to their successful training. They then stay on in a series of unsatisfactory posts, sometimes as locums, until, in their late ${ }^{N}$ 30 s or carly 40 s, married and with a family, they realise theyc have no prospects here or in their own country. With an understandable sense of grievance they are apt to blame the system for lack of training opportunities.

Certainly more could be done to give career guidance early? on. There are still some poor junior hospital posts despite efforts by hospital staff and postgraduate authorities to provide integrated senior house officer rotation schemes and the recent requirement by the General Medical Council that only postso approved for training by the royal colleges and faculties can be filled by doctors with limited registration. The Professional ando Linguistic Assessments Board test does ensure minimum 